\title{
When decisions on homologous structures cause ambiguous taxa relationships: the Neomorphinae (Aves, Cuculidae) example
}

\author{
Posso, SR. ${ }^{\mathrm{a} *}$ and Donatelli, RJ. ${ }^{\mathrm{b}}$ \\ ${ }^{a}$ Laboratório de Ecologia, Filogenia e Conservação de Aves Neotropicais, DCN, \\ Universidade Federal de Mato Grosso do Sul - UFMS, \\ CEP 79620-080, Três Lagoas, MS, Brazil \\ 'Laboratório de Vertebrados, Departamento de Ciências Biológicas - DCB, \\ Universidade Estadual Paulista - UNESP, \\ CEP 17033-360, Bauru, SP, Brazil \\ *e-mail: srposso@ hotmail.com
}

Received October 17, 2008 - Accepted February 6, 2009 - Distributed February 28, 2010

(With 18 figures)

\begin{abstract}
The anatomy of Neomorphinae is poorly understood and the systematics of this sub-family is also the most controversial of the cuckoo taxa, mainly with regard to the systematic position of Tapera and Dromococcyx. In this study, morphological similarities of the Neomorphinae are discussed after a comprehensive description of the cranial osteology was conducted in seven species, embracing all the Neomorphinae genera. This description is followed by comparisons with other cuckoos in order to contribute to the anatomy and systematics of this sub-family. In this way, we provide illustrations that enable the osteological descriptions and the proposed primary homologies to be visualised and compared. Even though Neomorphinae species share many cranial osteological characteristics, there are some anatomical divergences that allowed us to divide them into two distinct groups: (Dromococcyx/ Tapera) and (Morococcyx(Neomorphus/Geococcyx)). After comparisons among all cuckoos this study suggests that Neomorphinae are more similar to Crotophaginae and Couinae than to other sub-families of cuckoos. Our results contrast with a recent phylogenetic study based on morphological features, mainly because alternative interpretations to the primary osteological homologies in this study grouped Tapera and Dromococcyx with Cuculinae. Although morphological studies can be used in phylogenetic analysis, we demonstrated here that decisions in the interpretation of the homologies can provide ambiguous results.
\end{abstract}

Keywords: Neomorphinae, Cuculidae, cranial osteology, homology, phylogeny.

\section{Interpretações de homologias primárias e ambiguidade nas posições filogenéticas dos táxons: o exemplo nos Neomorphinae (Aves, Cuculidae)}

\begin{abstract}
Resumo
Neomorphinae é o grupo filogeneticamente mais controverso entre os cucos, em virtude da ambígua posição de Tapera e Dromococcyx, ainda, a anatomia do grupo é pouco compreendida. Neste estudo, as homologias primárias são discutidas em relação à osteologia craniana desta subfamília e comparadas aos demais Cuculiformes. O estudo propõe interpretações alternativas para homologias primárias dos caracteres cranianos em relação àquelas encontradas em filogenias com base nesta fonte de caracteres, na qual se observa Tapera e Dromococcyx agrupados dentro de Cuculinae. De modo a melhor demonstrar isto, os crânios foram descritos e ilustrados, apontando-se as homologias propostas e contrapondo-as com a literatura. Os resultados sugerem algumas variações entre os táxons que compõem a subfamília que permitem agrupá-los da seguinte maneira: (Dromococcyx/Tapera) e (Morococcyx(Neomorphus/ Geococcyx)). Ainda, comparando com as demais subfamílias, os Neomorphinae são similares a Crotophaginae e Couinae. Não obstante, os resultados demonstraram os táxons de Neomorphinae (incluindo Tapera e Dromococcyx) nitidamente mais similares entre si do que com qualquer outro grupo de cucos, indicando provável monofiletismo da subfamília, conforme sugerem os dados moleculares. No entanto a descrição da osteologia aqui apresentada difere do observado em uma filogenia com base em caracteres morfológicos e isto resulta das diferentes interpretações das homologias primárias adotadas em cada caso, causando hipóteses conflitantes entre si, como é demonstrado neste estudo.
\end{abstract}

Palavras-chave: Neomorphinae, Cuculidae, osteologia craniana, filogenia. 


\section{Introduction}

The anatomy of birds was the focus of systematic studies at the end of the $19^{\text {th }}$ century and at the beginning of the $20^{\text {th }}$ century. Although these studies contributed to the understanding of most bird groups, they did little to elucidate systematics at some categorical levels (e.g., family and genera); sampling at this time was insufficient to examine relationships at these levels and comparisons were made among taxa that were not closely related. Nevertheless, ornithologists have been conducting systematic studies with more rigidity in order to test the legitimacy of the characters used in traditional classifications such as those of Huxley (1867); Fürbringer (1888); Gadow (1892); Peters (1940) and Berger (1960). As a result, there are many osteological characters used in most orders of birds and also in some of the largest groups of birds (Livezey and Zusi, 2007). However, according to these last authors, the anatomy of birds has not been sufficiently studied yet, particularly in cuckoos.

Anatomical investigations of cuckoos are concentrated mainly at the beginning of the $20^{\text {th }}$ century (Shufeldt, 1901; Pycraft 1903; Peters, 1940; Verheyen, 1956); however few cranial osteological studies concerning Neomorphinae are available in the literature and the descriptions are restricted to the species representing them. The only study of osteology which includes all of the genera of Neomorphinae (Hughes, 2000) lacks detailed descriptions and figures for comparisons.

According to Payne (2005) Tapera and Dromococcyx are grouped with Morococcyx, Geococcyx and Neomorphus in the subfamily Neomorphinae, as observed in traditional classifications (Peters, 1940; Morony et al., 1975; Howard and Moore, 1998). They belong almost exclusively to the Neotropical region, except G. californianus (Payne, 2005). Generally speaking, the Neomorphinae are terrestrial, but Tapera and Dromococcyx show some arboreal behaviour and are brood parasitic birds (Payne, 2005).

Molecular phylogenies (Sibley and Ahlquist, 1990; Aragón et al., 1999; Payne and Sorenson, 2005) diverge most significantly from anatomical, ecological and behavioural studies (Seibel, 1988; Hughes, 1996 and 2000), primarily on whether Neomorphinae is or is not defined as a monophyletic group. The last authors pointed out that Neomorphinae is not monophyletic because Tapera and Dromococcyx are considered to be more closely related with Old World cuckoos (Cuculinae) than with other cuckoos. However, molecular studies were in agreement and indicated that Neomorphinae is a monophyletic group, close to Crotophaginae (Anis). Posso (1999) performed a cladistic analysis using only cranial osteological characters in the Neotropical cuckoos and Tapera and Dromococcyx were grouped with other Neomorphinae in all the most parsimonious trees. Posso and Donatelli (2006) performed a cladistic analysis on characters from cranial osteology with post-cranial, ecological and behavioural characters from Hughes (1996 and 2000) and concluded the systematic position of Tapera and Dromococcyx is unsolved, because the interpretations of primary homologies on the cranial features were different to those found in Hughes (2000).

In this study we provide a detailed description of the cranial features of Neomorphinae and also suggest alternative interpretations to the primary homologies (sensu de Pinna, 1991) in Hughes (2000). We also provide illustrations enabling the osteological descriptions and the proposed primary homologies to be visualised and compared.

Specifically, our goals are: 1) to provide a detailed comparative description of the cranial osteology of the Neomorphinae species; 2) to relate the Neomorphinae species and to compare them with other cuckoos; and 3) to discuss interpretations in the primary homologies and phylogeny implications according to this description.

\section{Material and Methods}

This study is based on the investigation of 54 specimens all of the species attributed to Neomorphinae (sensu Payne, 2005) except Neomorphus pucheranii, $N$. radiolosus and $N$. rufipennis. Specimens of Neomorphus are difficult to collect and thus are rare in osteological collections. The specimens came from the collections of the Museum of Vertebrate Zoology (MVZ), University of California, Berkeley, California, USA; the Museum of Zoology (UMMZ), University of Michigan, Ann Arbor, Michigan, USA; the United States National Museum (USNM), Smithsonian Institution, Washington, DC, USA; the American Museum of Natural History (AMNH), New York, USA and the Museu de História Natural de Taubaté (MHNT), Taubaté, São Paulo state, Brazil. Geococcyx californianus (Lesson, 1829): MHNT 110; MVZ 176050, 7588; UMMZ 116179, 201069, 227058, 227059, 234551, 234552, 236211, 73880, 73881, 85031; USNM 1461 17486, 346493, 499279, 501304, 554946, 554948, 610961, 610962, 614371. G. velox (Wagner, 1836): AMNH 2167; MVZ 85646, 85647; UMMZ 152883, 156461, 156462, UMMZ 159112. Morococcyx erythropygus (Lesson, 1842): AMNH 4604; MVZ 156635, 85641; UMMZ 130940, 133738, 209205. Neomorphus geoffroyi (Temmnick, 1820): UMMZ 200592, 431345, 432636. Dromococcyx pavoninus Pelzeln, 1870: UMMZ 209207. D. phasianellus (Spix, 1824): MVZ 85638. Tapera naevia (Linnaeus, 1766): MHNT 1036; MVZ 141740, 94088; UMMZ 135167, 209208, 214004, 214005, 218370, 218946, 222217; USNM 19221, 321520, 346329.

Moreover, because of the controversy regarding the monophyly of Neomorphinae, we decided to perform a comparison using a dense taxa sampling approach, studying and comparing a further 508 specimens in 73 species, including all genera of Cuculidae (except Scythrops, Pachycoccyx, Cercococcyx, Caliechthrus and Microdynamis). The list of these specimens is found in Posso and Donatelli (2006). 
In order to avoid misclassification in relation to bony boundaries, we followed the osteological study of young cuckoos in Posso and Donatelli (2005). The Nomina Anatomica Avium proposal (Baumel and Witmer, 1993) is used as a reference for osteological structure nomenclature, but new nomenclature suggestions for some features in Posso and Donatelli (2005) were also used.

We followed Payne (2005) for species nomenclature and classification.

\section{Results and Discussion}

In the frontal region (F, Figure 1) all species present a rostral depression (D1, Figures 1 and 2) in the zona flexoria craniofacialis. The lateral extremities of the dorsal surface between orbits are narrower than the parietal roof (calvaria). Tapera (Figure 1) and Dromococcyx have the narrowest lateral extremities, and the parietal region is three times broader than the orbital region in these species. In N. geoffroyi (Figure 2), Morococcyx, and Geococcyx, the parietal is about two times broader than the orbital region.

The cerebellar prominence (PC, Figures 3, 4) is higher and broader in Dromococcyx (Figure 6) than in other species, so that the skull is more elongated in Dromococcyx.

The basilar tubercle (TB, Figures 3, 4 and 1014) of the rostral portion of the basioccipital region (B, Figure 10) has a moderately prominent crest-shape that is not prominent in Geococcyx (Figure 4). The subcondylar fossa (Fsc, Figure 14) surrounds the rostral portion of the condyle and is deeper in Morococcyx, N. geoffroyi and Geococcyx.

The rostral extremity (basi rostri parasphenoidalis, PjP, Figures 10-14) of the parasphenoid region (PS, Figure 10) is larger and more rounded in N. geoffroyi (Figure 13) than in other Neomorphinae. The lateral parasphenoidal process (PrlP, Figures 3, 4) is slightly developed, forming the large hiatus subtympanicus and projects ventrally with a tapering extremity in Morococcyx, N. geoffroyi and Geococcyx (Figure 4). This process is larger (well-developed and rounded) in Tapera and Dromococcyx (Figure 3) when compared with other Neomorphinae.

The ectethmoid bone (Ec, Figure 5) is slender and its dorsal portion (facies nasalis) $(\mathrm{Pj} 1$, Figures 5-9) is short laterally and there is no contact with the lacrimal bone. The ventral portion (facies orbitalis) ( $\mathrm{Pj} 2$, Figures 5-14) has a ventral extremity that is rounded and broad and a lateral extremity that is concave because the ectethmoid is narrower between its projections. The form of the ectethmoid of Dromococcyx is an exception (Figure 6); the lateral extremity in this species is straight and the ventral projection is laterally larger than in other Neomorphinae species. The uncinate bone (os uncinatum) is narrow and long and was observed only in some specimens of N. geoffroyi and Geococcyx species.
The supraorbital process (PrS, Figures 1, 2, 5-9) of the lacrimal (L, Figure 5) is thick, long and large in all Neomorphinae. The nasolacrimal suture (NLS, Figures 1, 5) is shorter in Morococcyx (Figure 7), N. geoffroyi (Figures 2, 8) and Geococcyx (Figure 9) because the lacrimal has little contact with the nasal bone in these species. The supraorbital process is larger laterally in Tapera (Figure 1), and in the Geococcyx species (Figure 9) this process has a medial shallow depression. The orbital process (PrO, Figures 5-14) of the lacrimal is broad laterally, and is thick and long (close to the jugal arch). Its ventral extremity is triangular in shape and has a caudolateral protuberance ( $\mathrm{CPj}$, Figure 10). In Geococcyx (Figure 14), this extremity is broader and thicker, and in contact with the jugal arch. The lacrimal bone is larger, longer and thicker in Geococcyx (Figures 9 and 14) than in other species. In Morococcyx, N. geoffroyi and Geococcyx (Figures 7-9) the orbital process of the lacrimal bone is perpendicular to the braincase, while in Dromococcyx and Tapera (Figures 5 and 6) the process is moderately oblique.

In Tapera, N. geoffroyi and G. velox (Figures 5, 8, 9), the processus squamosalis (PrSq, Figures 5-9) extends between one half and one third of the distance between its origin in the skull and the jugal arch. In Morococcyx (Figure 7), this process is flatter, broader and longer, accounting for about two-thirds of the above distance, and for about one quarter and one fifth of this distance in Dromococcyx (Figure 6) and G. californianus. A conspicuous bony trabecula (T1, Figures $6,7,11,12$ ) is located at the rostral extremity of the squamosal process in Dromococcyx and Morococcyx. This trabecula is short and broad in Morococcyx (Figures 7, 12) but long and narrow in Dromococcyx (Figures 6, 11). The transverse crest (crista temporalis transversa) ( $\mathrm{TrC}$, Figures 5-9) is more prominent in Tapera and Morococcyx (Figures 5 and 7). The temporal fossa does not reach the caudal portion of the skull but is confined to the lateral portion, and is deeper in N. geoffroyi and Geococcyx (Figures 8 and 9) than in other Neomorphinae species. The subtemporal fossa (FST, Figure 5) is narrow caudally in N. geoffroyi and Geococcyx (Figures 8, 9). Tapera and Dromococcyx show a tubercle on the ventrolateral surface of the subtemporal fossa.

The postorbital process (PrPo, Figures 5-9) is more reduced in Tapera (Figure 5) and N. geoffroyi (Figure 8): it varies in length from one fifth to one sixth of the distance between its origin in the cranium and the jugal arch. This length is longer (a quarter of this distance) in Geococcyx (Figure 9) and is particularly short in Dromococcyx (Figure 6) and Morococcyx (Figure 7), where it is less than one seventh of the specified distance. Moreover, in Dromococcyx the postorbital process is laterally narrow.

The fossa laterosphenoidales is shallow (FL, Figure 5) but deeper and larger in N. geoffroyi, Morococcyx and Geococcyx. In Dromococcyx a bony trabecula (T2, Figure 6) is attached to the tuberculum 

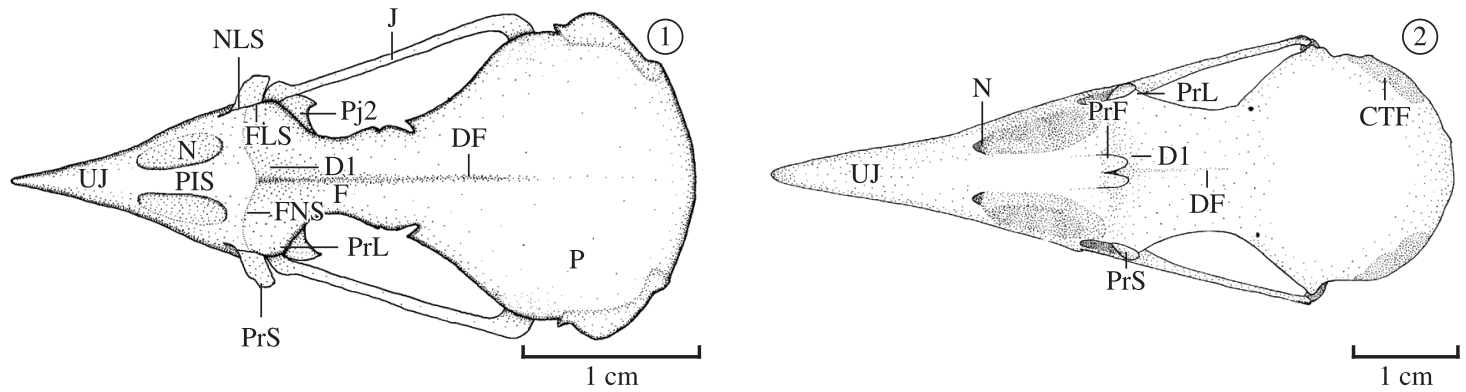

Figures 1-2. Dorsal view of the skulls of (1) Tapera naevia; and (2) Neomorphus geoffroyi. D1 - rostral depression of the frontal; DF - depressio frontalis; F - frontal region; FLS - frontolacrimal suture; FNS - frontonasal suture (fissura zona flexoria craniofacialis); $\mathrm{J}$ - jugal arch; $\mathrm{N}$ - nostril; NLS - nasolacrimal suture; $\mathrm{P}$ - parietal region; $\mathrm{Pj} 2$ - ventral projection of the ectethmoid; PIS - Pila supranasalis; PrF - processus frontalis of the nasal bone PrL - processus lacrimalis; PrS - processus supraorbitalis; UJ-upper jaw.
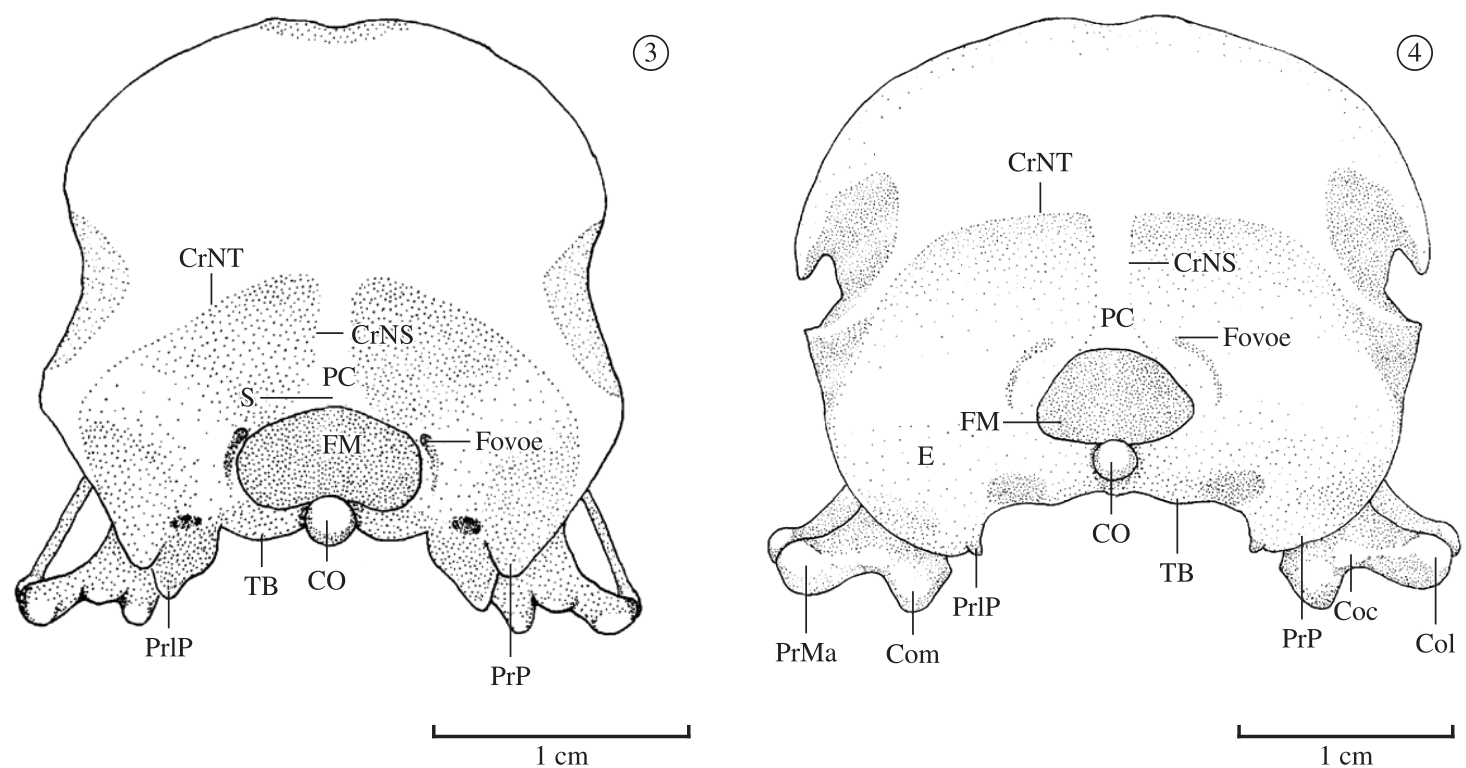

$1 \mathrm{~cm}$

$1 \mathrm{~cm}$

Figures 3-4. Caudal view of the skulls of (3) Dromococcyx phasianellus; and (4) Geococcyx velox. CO - condylus occipitalis; Coc - condylus caudalis; $\mathrm{Col}$ - condylus lateralis; Com - condylus medialis; CrNS - crista nuchalis sagitalis; CrNT - crista nuchalis tranversalis; E - exoccipital region; FM - foramen magnun; Fovoe - foramen venum occipitalis externae; PC - proeminentia cerebellaris; PrMa - processus mandibularis os quadrati; PrlP - processus lateralis parasphenoidalis; PrP - processus paraoccipitalis; $\mathrm{S}$ - supraoccipital region; TB - tuberculum basilaris.

parasphenoidale and it is narrower, tapered and smaller than trabecula 1 of the squamosal region.

The orbitocranial fontanelle (FOC, Figures 5-9) of the interorbital septum shows a smaller aperture in Geococcyx (Figure 9) than in other Neomorphinae.

The rostral wall of the orbit (paries rostralis orbitae) contains a narrow and shallow sulcus for the olfactory nerve (SuO, Figure 6). The medial orbitonasal foramen (Form, Figures 6-9) is larger in N. geoffroyi and Geococcyx (Figures 8 and 9). The lateral orbitonasal foramen is extremely reduced or absent in Tapera and Dromococcyx.

The upper jaw (UJ, Figures 1, 2, 5-9) is approximately one half of the total length of the skull in all
Neomorphinae, except in Geococcyx, in which the upper jaw is approximately two-thirds of the skull length. In D. phasianellus (Figure 6), the upper jaw is narrower than in the other species, and in Tapera (Figure 1) it is shorter and larger. The rostral apex of the upper jaw is more ventrally curved in Tapera (Figure 5). Geococcyx shows an elongated elevation on the mediocaudal surface of the upper jaw. This elevation is more prominent in $G$. velox than in G. californianus.

The nasal aperture (N, Figures 1, 2, 5-9) is partly covered by a bony lamella in all species of Neomorphinae. However, in Morococcyx, N. geoffroyi (Figure 8) and Geococcyx (Figures 7, 8, 9) this lamella is broader than in Tapera (Figures 1, 5) and Dromococcyx (Figure 6) 
because it covers the caudal portion of the nostril. In Tapera (Figures 1, 5) and Dromococcyx (Figure 6) it covers only the dorsocaudal portion. In the ventral surface of the nostril, all species present a short crest $(\mathrm{NCr}$, Figures 5, 6), but in Morococcyx it is longer. N. geoffroyi (Figure 8) has a discrete, laterally flattened elevation (SNE, Figure 8) on the dorsal surface of the supranasal region (PIS, Figure 1) rostroventral surface of the premaxillary bones. The laterally flattened jugal process (PrJ, Figures 5-9) is broader in Dromococcyx, Tapera and N. geoffroyi (Figures 5, 6, 8).

All species present a conspicuous depression between the maxillopalatine processes (PrMP, Figures 10-14), but this depression is deeper in Tapera and Dromococcyx (Figures 10, 11).

The maxillary process (PrM, Figures 10-14) of the palatine (Pal, Figures 5, 10) is narrower in the rostral region in Tapera and Dromococcyx (Figures 10, 11). The palatine bone broadens out laterocaudally, especially in $N$. geoffroyi (Figure 13), where its breadth covers almost the entire distance between the jugal arches. The narrow choanal fossa (fossa choanalis, Fc, Figures 10-14) has a rostral projection ( $\mathrm{RPj}$, Figure 11) and it is longer in Dromococcyx (Figure 11).

In Morococcyx, N. geoffroyi and Geococcyx (Figures 7-9) the choanal lamella (LC, Figures 5-9) is absent. The pterygoid process (PrPt, Figures 10-14) is short in Tapera (Figure 10), Morococcyx (Figure 12) and Geococcyx (Figure 14). It is reduced and laterally wide in N. geoffroyi (Figure 13) and longer in Dromococcyx (Figure 11).

The pterygoid (Pt, Figures 5, 10) presents a thin plate (proc. dorsalis, PrD, Figure 5) in Morococcyx, Dromococcyx and Tapera. However, in N. geoffroyi (Figure 8) and Geococcyx (Figure 9) the pterygoid is flat (the dorsal process is absent).

The orbital process (PrOr, Figure 5) of the quadrate bone is short and rounded in N. geoffroyi and Geococcyx (Figures 8, 9). In the other species, the orbital process is longer and narrower.

The lateral (Col, Figures 4, 11) and medial (Com, Figures 4,11) condyles of the quadrate are of practically the same size in Tapera, Dromococcyx (Figure 3) and Morococcyx, but in N. geoffroyi and Geococcyx (Figure 4) the lateral condyle is larger than the medial condyle.
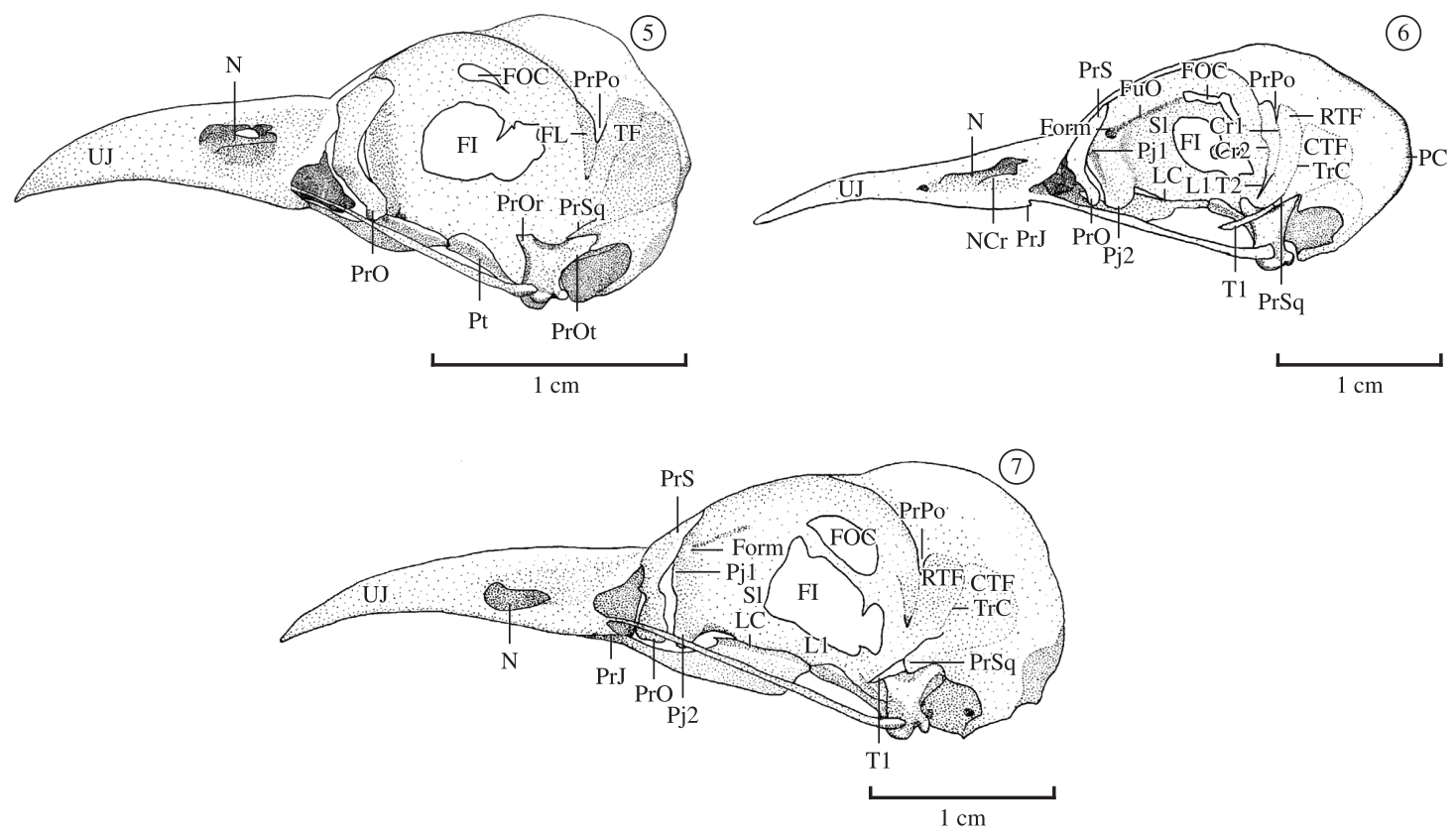

Figures 5-7. Lateral view of the skull of (5) Tapera naevia; (6) Dromococcyx phasianellus; and (7) Morococcyx erythropygus. $\mathrm{Cr} 1$ and 2 - lateral (1) and medial (2) crests of the fossa laterosphenoidalis (caudal orbit); CTF - caudal temporal fossa; Ec ectethmoid bone; FL - fossa laterospheinoidalis; FI - fonticuli interorbitales; FOC - fonticuli orbitocraniales; Form - foramen orbitonasalis medialis; FST - fossa subtemporalis; J - jugal arch; L - lacrimal bone; L1 - dorsal lamina of the parasphenoid rostrum; LC - lamela choanalis; MAE - meatus acusticus externus; $\mathrm{N}$ - nostril; $\mathrm{NCr}$ - nasal crest; NLS - nasolacrimal suture; $\mathrm{Pal}$ - palatine bone; PC - prominentia cerebelaris; Pj1 and 2 - dorsal (1) and ventral (2) ectethmoid projections; PrJ - processus jugalis; PrO - processus orbitalis of the lacrimal bone; PrOr - processus orbitalis of the quadrate bone; PrOt - processus oticus of the quadrate bone; PrPo - processus postorbitalis; PrS - processus supraorbitalis; PrSq - processus squamosalis; Pt - pterygoid bone; RTF - rostral temporal fossa; SI - septum interorbitalis; T1 - trabecula of the squamosal process; T2 trabecula of the tuberculum paraspheinoidalis; TF - temporal fossa; TrC- transversal crest (crista temporalis transversa); UJ - upper jaw. 

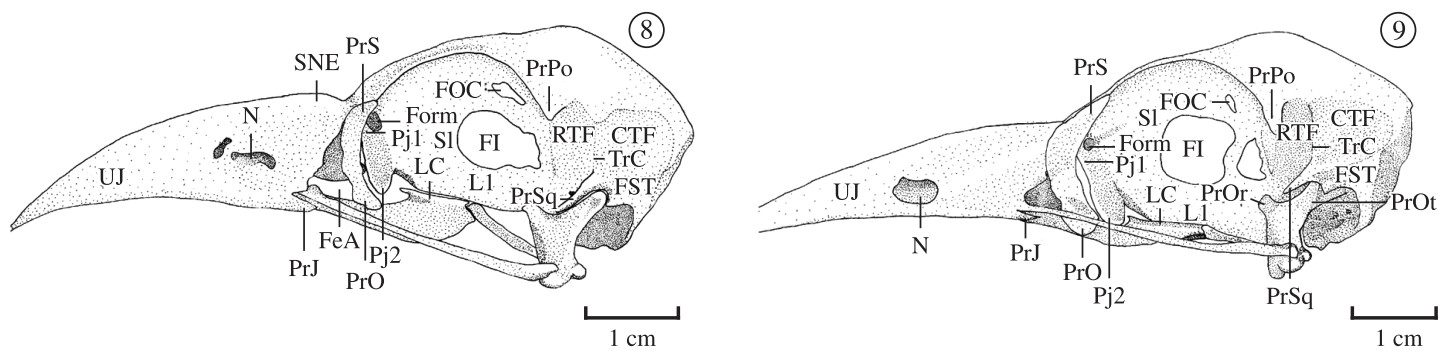

Figures 8-9. Lateral view of the skulls of (8) Neomorphus geoffroyi; and (9) Geococcyx velox. CTF - caudal temporal fossa; FeA - fenestra antorbitalis; FI - fonticuli interorbitales; FOC - fonticuli orbitocraniales; Form - foramen orbitonasalis medialis; FST - fossa subtemporalis; L1 - dorsal lamina of the parasphenoid rostrum; LC - lamela choanalis; N - nostril; Pj1 and 2 - dorsal (1) and ventral (2) ectethmoid projections; PrJ - processus jugalis; PrO - processus orbitalis of the lacrimal bone; PrOr - processus orbitalis of the quadrate bone; PrOt - processus oticus of the quadrate bone; PrPo - processus postorbitalis; PrS - processus supraorbitalis; PrSq - processus squamosalis; RTF - rostral temporal fossa; SI - septum interorbitalis; SNE supranasal expansion; TrC - transversal crest (crista temporalis transversa); UJ - upper jaw.
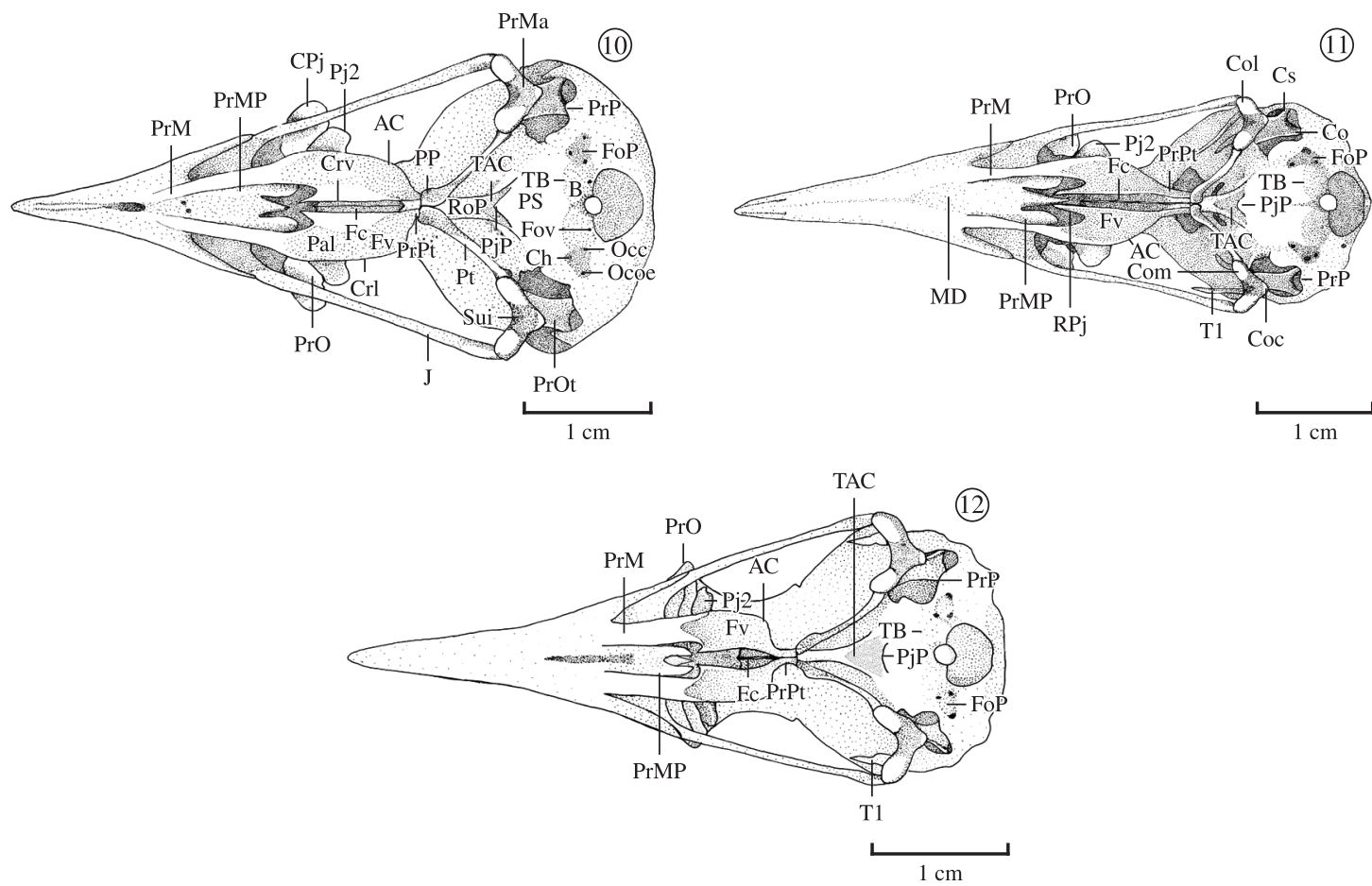

Figures 10-12. Ventral view of the skulls of (10) Tapera naevia; (11) Dromococcyx phasianellus; and (12) Morococcyx erythropygus. AC - angulus caudolateralis; B - basioccipital region; Ch - canalis n. hypoglossi; Co - capitulum oticum; Coc - condylus caudalis; $\mathrm{Col}$ - condylus lateralis; $\mathrm{Com}$ - condylus medialis; $\mathrm{CPj}$ - caudolateral projection of the orbital process of the lacrimal bone; Crl - crista lateralis; Crv - crista ventralis; Cs - capitulum squamosum; Fc - fossa choanalis; FoP - fossa parabasalis; Fov - foramen n. vagi; Fv - fossa ventralis; J - jugal arch; MD - medial depression in the palatine region; Occ ostium canalis carotici; Ocoe - ostium canalis ophthalmici externi; Pal - palatine region; Pj2 - ventral ectethmoid projection; $\mathrm{PjP}$ - parasphenoid projection; PP - pars palatina of the pterygoid; PrM - processus maxillaris; PrMa - processus mandibularis of the quadrate bone; PrMP - processus maxillopalatinus; PrO - processus orbitalis; PrOt - processus oticus; PrP - processus paraoccipitalis; PrPt - processus pterygoideus; PS - parasphenoid region; Pt - pterygoid bone; RoP - rostrum parasphenoidale; $\mathrm{RPj}$ - rostral projection of the ventral crest; Sui - sulcus intercondylaris; T1 - trabecula of the squamosal process; TAC - tuba aditiva communis; TB - tuberculum basilaris. 

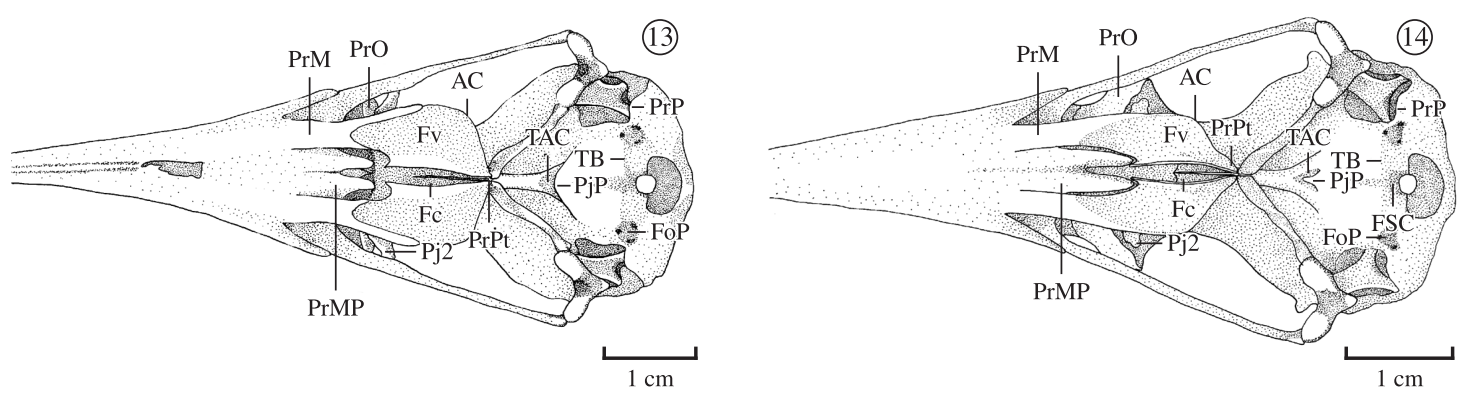

Figures 13-14. Ventral view of the skull of (13) Neomorphus geoffroyi; and (14) Geococcyx californianus. AC - angulus caudolateralis; Fc - fossa choanalis; FoP - fossa parabasalis; Fsc - fossa subcondylaris; Fv - fossa ventralis; Pj2 - ventral ectehmoid projection; $\mathrm{PjP}$ - parasphenoid projection; PrM - processus maxillaris; PrMP - processus maxillopalatinus; PrO - processus orbitalis; PrP - processus paraoccipitalis; PrPt - processus pterygoideus; TAC - tuba aditiva communis; TB - tuberculum basilaris.
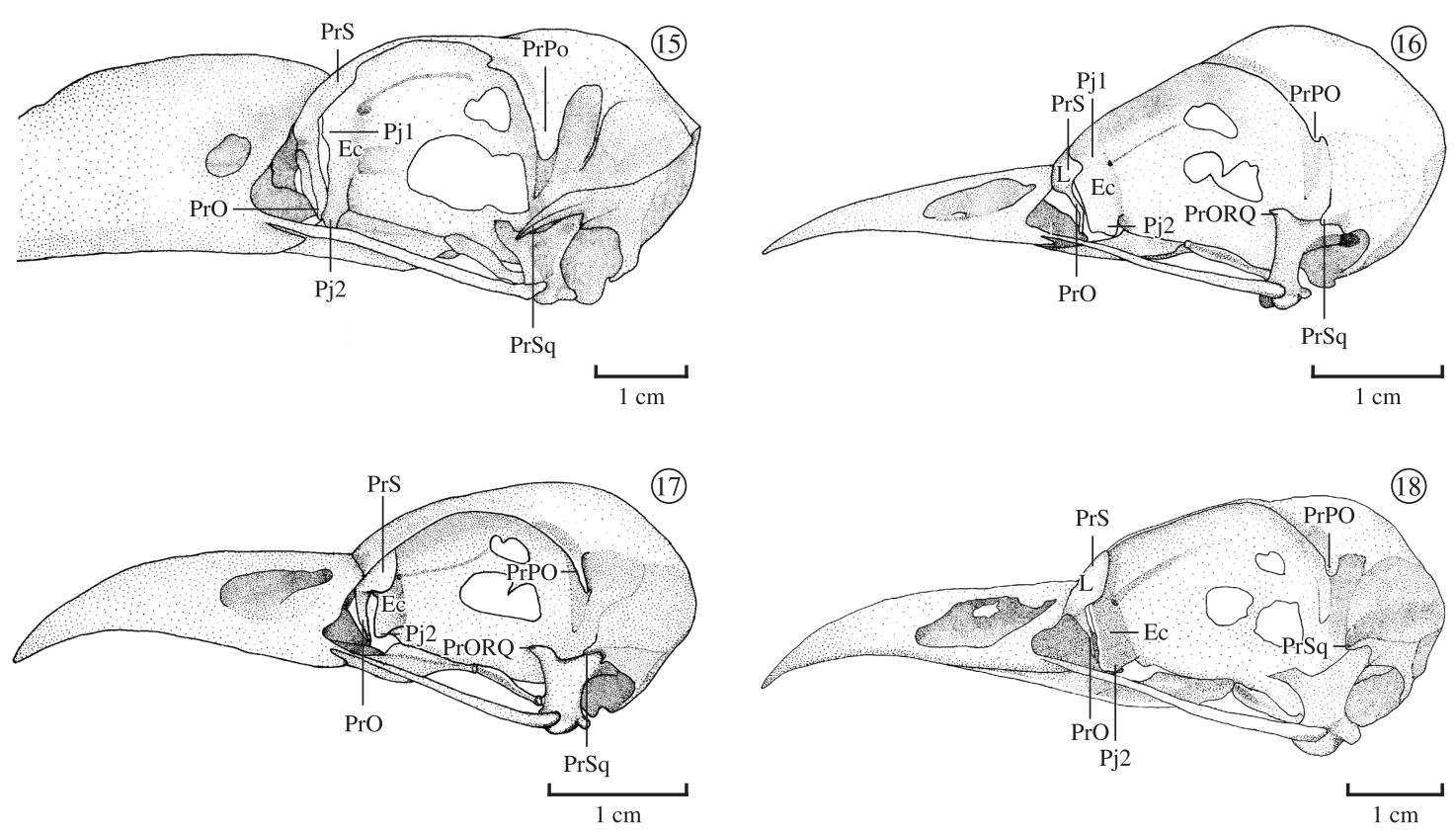

Figures 15-18. Lateral view of the skulls of (15) Crotophaga major (Crotophaginae); (16) Chrysococcyx basalis (Cuculinae); (17) Ceuthomochares aereus (Phaenicophaeinae); and (18) Hyetornis rufigularis (Coccyzinae). Ec - ectethmoid bone; L - lacrimal bone; Pj1 and 2 - dorsal (1) and ventral (2) ectethmoid projections; PrO - processus orbitalis of the lacrimal bone; PrOrQ - processus orbitalis of the quadrate bone; PrPo - processus postorbitalis; PrS - processus supraorbitalis; PrSq - processus squamosalis.

The mandible is long and narrow, with a total length equivalent to three times the distance between the two mandibular rami (ramus mandibulae) in all species of Neomorphinae.

The symphysial portion (pars symphysialis) accounts for roughly a quarter of the total length of the mandible in all species except Tapera where it accounts for approximately a fifth of this distance. The rostromedial surface of the mandible has a long and deep fossa.

The fenestra caudalis is partially covered by a thin bony lamella. In $N$. geoffroyi, this lamella covers nearly the entire aperture.
The medial surface of the medial process has a welldeveloped tubercle and the caudal surface of the mandible has a broad shallow fossa in all species.

Within the Neomorphinae, there are five characteristics that are shared by the group Geococcyx, Morococcyx and Neomorphus that differ from Tapera and Dromococcyx: the lateral length of the frontal is larger, the lateral process of the parasphenoid is reduced, the lateral orbitonasal foramen is larger, the bony lamella covering the nasal aperture is larger and the dorsal process of the nasal is absent. Geococcyx and Neomorphus are very similar to each other, sharing most of the osteologi- 
cal features distinct from Morococcyx (see description). G. velox and G. californianus are just distinguished from each other by the size of the skull and by the different development pattern of the squamosal process and medial orbitonasal foramen.

This study demonstrated that Tapera is quite similar to Dromococcyx, sharing several characteristics. Dromococcyx presents four characters that are unique to this genera, but there are no qualitative differences in the cranial osteology between $D$. phasianellus and D. pavoninus. Tapera naevia presents two peculiar features in the development of the lateral parasphenoid process and the peculiar form of the caudal extremity of the orbital lacrimal process.

\subsection{Comparisons of primary homologies and system- atic implications}

The medial parasphenoid process is absent in all cuckoo species studied, thus confirming Bock's description (1960). However, the lateral parasphenoid process varies among cuckoos. It is most developed and continuous with the paraoccipital process in Tapera, Dromococcyx and species of Coua, Carpococcyx and Crotophaginae. In Geococcyx, Neomorphus and Morococcyx it is practically absent.

The literature contains few detailed descriptions of the ectethmoid in Neomorphinae (Shufeldt, 1901; Pycraft, 1903). Although few variations in the ectethmoid are observed in Neomorphinae, ectethmoid is more heterogeneous among other cuckoos. Species of Crotophaginae (Figure 15) show a reduced ventral projection of the ectethmoid, while in species of Cuculinae (Figure 16), Coccyzinae (Figure 18) and Phaenicophaeinae (Figure 17) both projections are broader laterally. One of the few variations in this bone among species of Neomorphinae is found in Neomorphus geoffroyi, Morococcyx and Geococcyx, where the dorsal process is less developed and is partially fused with the mesethmoid, thus providing a large aperture for the medial orbitonasal foramen. The same is true of Crotophaga (Crotophaginae) and Coua, Centropus and Carpococcyx. This feature can probably be attributed to different degrees of ossification in the dorsal process of the ectethmoid and mesethmoid, as observed by Pycraft (1903).

Pycraft (1903) regarded the variations in the lacrimal as a key criterion for distinguishing between species and for classifying certain genera within Cuckoos. This conclusion is borne out by descriptions of the lacrimal in the species of Neomorphinae and other cuckoos studied here, with variations occurring at the genus level (Figures 5 to 9).

Pycraft (1903) noted that in cuckoos, the temporal fossa extends to the caudal portion of the skull. No such pattern of temporal fossa was observed in the species of Neomorphinae described here. In the species studied this fossa does not extend as far as the caudal portion of the skull (Figures 3, 4). However, the pattern described by Pycraft (1903) can be found in species of Centropus,
Crotophaginae, Phaenicophaeinae and Coccyzinae (Figures 15, 17, 18).

The bony trabecula on the squamosal process in Dromococcyx and Morococcyx may be an ossified aponeurosis (T1, Figures 6, 7). In a study of the pattern of temporal fossa found in Anseriformes and Galliformes, Zusi and Livezey (2000) observed that the postorbital and squamosal processes in most Galliformes are connected by an ossified aponeurosis at the rostral extremity of the squamosal process. Given the difficulty of homologising this structure in Galliformes with that found in Cuculiformes, we decided to refer to it as bony trabecula.

Generally speaking, our description of the upper jaw of Neomorphinae matches that of Pycraft (1903). The shape of the external nasal aperture is significantly modified in cuckoos, likely owing to different levels of ossification of the bony lamella in the nasal and maxillary bones. For example, in Neomorphus geoffroyi, Morococcyx erythropygus and Geococcyx (Figures 7 to 9) a thin plate of bone covers most of the nasal aperture, whereas in Tapera naevia and Dromococcyx phasianellus the nasal aperture is more open (Figures 5, 6). Clamator glandarius (Cuculinae) presents the same pattern as Morococcyx, N. geoffroyi and Geococcyx. In Crotophaga (Posso and Donatelli, 2001; Figure 15), the nasal aperture is positioned ventrolaterally and the external aperture is small and circular. Beddard (1885) described a similar appearance of the nasal aperture in Scythrops (Cuculinae). Moreover, some species of Phaenicophaeinae and Coccyzinae present the bony lamella covering the nasal aperture in different levels of ossification.

The palatal region as described here is similar to those described elsewhere (Huxley, 1867; Beddard, 1885; Shufeldt, 1901; Pycraft, 1903). Moreover, we observed that the palatine bone is almost identical in all species of Neomorphinae and very similar to the other terrestrial cuckoos (Centropodinae and Crotophaginae), especially as far as its desmognathous condition is concerned, as classified by Huxley (1868). The pterygoid differs only with regard to the presence or absence of a dorsal process (PrD, Figures 5 to 9) and of a rostral expansion.

Descriptions of mandibles are found in Pycraft (1903), albeit with little detail, and in Marceliano (1996), which has more detail but gives no reference to species of Neomorphinae. The mandibles are very heterogeneous in other cuckoo genera, but are very similar in Neomorphinae. There is a single difference between Neomorphus geoffroyi and other Neomorphinae species in the mandibular aperture (fenestra mandibulae) that may reflect different degrees of ossification in the supra-angular and dental bones. According to Jollie (1957), the mandibular aperture penetrates the ossification margins of these bones.

Hughes (2000) cites eight cranial characters grouping Tapera and Dromococcyx with Cuculinae, Coccyzinae and Phaenicophaeinae. We agree with Hughes only with regard to the narrower distance between the edges of the frontal bone (see Tapera and Dromococcyx, Figures 1, 2) and in addition we found another similar character in 
these groups: the fossa laterospheinoidale, in the caudal portion of the orbit, is narrow (Figures 5-8 and 15-18).

We did not observe the character 31 from Hughes (the shape of the optic region in the lateral aspect) because the quadrate bone was obliterating this region in the specimens studied. Thus we cannot make any inference from this character. However, as for the other characters that were used to consider Tapera and Dromococcyx in the Cuculinae clade (characters 5, 24, 33, 34, 37, 45 in Hughes, 2000), we believe that the following homologies established by Hughes are questionable:

a) The size and shape (flattened rostrocaudally) of the proc. postorbitalis (character 5 of Hughes, 2000) are very similar in all Neomorphinae (Figures 5, 6, 7 ) as well as in other cuckoos (Figures 15, 17, 18). In Cuculinae the process differs consistently from that found in other cuckoos, where the process is small in size and tubercular in shape (Figure 16);

b) We found no differences in the angle of the proc. oticus and proc. orbitalis of the os quadratum in the lateral aspect (character 24 of Hughes, 2000) among species of Neomorphinae (Figures 5 to 9). The only differences observed were in the size of the orbital process (proc. orbitalis) but these were heterogeneous among specimens of same species;

c) Contrary to Hughes' (2000) observations, Tapera and Dromococcyx are similar to Neomorphus and Morococcyx (Figures 10-13) in the form of the crista basilaris transversa (characters 33, 34 of Hughes), as are all other cuckoos except Geococcyx (Figures 4, 14), Crotophaginae, Carpococcyx and some species of Coua and Centropus;

d) Although the elevation of the "bulbous" of $o s$ exoccipitale (character 37 of Hughes) is not prominent in Geococcyx and Neomorphus, in Morococcyx it is as salient as in Tapera and Dromococcyx and the Cuculinae species. This could be a plesiomorphy for Neomorphinae and could have been reduced in Geococcyx and Neomorphus in a secondary event; and

e) The rostral expansion in the facies ventralis of the os pterygoideum (character 45 of Hughes, 2000) is present only in Musophagidae, Carpococcyx and Coua, but in Neomorphinae species, as well as in all other cuckoos, it is either absent or much smaller (Figures 10 to 14).

The Neomorphinae is more similar to the other terrestrial cuckoos (Crotophaginae and Centropodinae) mainly in the ectethmoid and lacrimal bones, and in the frontal region. The lacrimal bone is thicker and longer in these subfamilies, and is free in relation to the ectethmoid (there is no contact between them). This is probably because both lateral and ventral projections of the ectethmoid are narrower than in the arboreal cuckoos (Coccyzinae, Phaenicophaeinae and Cuculinae). The cranial roof of the orbital portion of the frontal region is broad between the orbits of the Neomorphinae and Crotophaginae when compared with the arboreal cuckoos (Coccyzinae,
Cuculinae and Phaenicophaeniae). Furthermore, the following differences are outstanding among terrestrial and arboreal cuckoos: the squamosal process is progressively longer, sharper and is obliquely projected, as well as the orbital process of the quadrate bone.

After the comparison with other subfamilies of cuckoos, we noticed that the Neomorphinae species are characterized as having several shared similarities, mainly in the form and size of the lacrimal and ectethmoid bones. Contrary to Hughes' (2000) results, the comparison with other cuckoos indicated many similarities of the cranial skeleton among the genera of Neomorphinae: the basilar tubercle is prominent; the hiatus subtimpanicus is broad (Figures 10 to 14); the supraorbital process of the lacrimal is long and large (Figures 5 to 9); the orbital process of the lacrimal is long and thick (Figures 5 to 9); the caudolateral protuberance of the lacrimal is present; the curvature of the rostral portion of the upper jaw is vestigial or absent (Figures 5 to 9); the bony lamella covers the nasal aperture, except for the rostral portion (Figures 5 to 9); the crest on the ventral surface of the nasal aperture is present (Figures 5 to 9); the choanal fossa is narrow (Figures 10 to 14); the medial tubercle of the medial process of the mandible is large and prominent; and the caudal fossa of the mandible is broad.

This examination of cranial osteology demonstrated that there are few similarities among Tapera/Dromococcyx and Cuculinae species. An alternative interpretation to support the removal of Tapera and Dromococcyx from the Neomorphinae would imply considering all eleven similarities mentioned above as symplesiomorphies for the Neomorphinae, since the terrestrial cuckoos are considered to be the basal group (Seibel, 1988; Hughes, 2000; Posso and Donatelli, 2006). However, this is not congruent with choosing either the Musophagidae or Galloanserimorphae as out-groups, as in Posso (1999) and Posso \& Donatelli (2006).

The anatomical hypothesis that proposes to group Tapera and Dromococcyx with Neomorphus, Geococcyx and Morococcyx (as has been shown herein) corroborates the findings of recent molecular studies (Sibley and Ahlquist, 1990; Payne and Sorenson, 2005) and also the common distribution in the Neotropical region. Thus, in this case it is plausible to assume that the few similarities among Tapera, Dromococcyx and species of Cuculinae are due to convergences.

We used cranial osteological features with post-cranial, ecological and behavioural characters from Hughes $(1996,2000)$ to perform a cladistic analysis of Cuculidae (Posso \& Donatelli 2006) and it showed that Tapera and Dromococcyx should be placed in the most basal branch within an arboreal assemblage (Coccyzinae, Phaenicophaeninae and Cuculinae). Nevertheless, differences when compared with Hughes (2000) are probably the result of different interpretations of primary homologies on the osteological features.

Lastly, these problems indicate that the position of Tapera and Dromococcyx within Cuculidae was prob- 
lematic in our study (Posso \& Donatelli 2006) and justify further cladistic analysis. All data examined together (total evidence, sensu Kluge 1989), using all of the information available in cladistics approaches among cuckoos, could potentially be used to determine the controversial systematic position of Tapera and Dromococcyx. Moreover, although morphological investigation is a valid method for obtaining characters to be used in phylogenetic analysis, the decisions in the interpretation of the homologies can provide ambiguous results, as has been shown herein.

Acknowledgements - We are indebted to Elizabeth Höfling, Richard L. Zusi and to anonymous reviewers for their critical reading of the manuscript and also to Kevin Mundy and Donald P. Eaton for English versions. We are grateful to the curators of the following museums for lending us their specimens: the Museum of Vertebrate Zoology (MVZ), Berkeley, USA; the Field Museum of Natural History (FMNH), Chicago, USA; the American Museum of Natural History (AMNH), New York, USA; and to the following museums for permitting us to study their collections: the Museu Paraense Emílio Goeldi, Belém, Brazil, with particular thanks to Maria L. V. Marceliano and David Oren; the National Museum of Natural History (USNM), Washington, DC, USA, with thanks to Storrs L. Olson, Gary R. Graves, Richard L. Zusi and the staff of the Division of Birds of the USNM; the Museum of Zoology, University of Michigan (UMMZ), Ann Arbor, USA, with thanks to Robert Payne; and to the Museu de História Natural de Taubaté (MHNT), with thanks to Herculano M. F. Alvarenga. This research was supported by FAPESP (grants 97/05672-2 and 99/08000-0).

\section{References}

ARAGÓN, S., MOLLER, AP., SOLER, JJ. and SOLER, M., 1999. Molecular phylogeny of cuckoos supports a polyphyletic origin of brood parasitism. Journal of Evolutionary Biology, vol. 12, no. 1, p. 495-506.

BAUMEL, JJ. and WITMER, LM., 1993. Osteologia. In BAUMEL, JJ., KING, AS., BREAZILE, JE., EVANS, HE. and VANDEN-BERGE, JC. (Eds.). Handbook of avian anatomy: Nomina anatomica avium. 2 ed. Cambridge: Nuttall Ornithological Club. p. 45-132.

BEDDARD, FE., 1885. On the structural characters and classification of the cuckoos. Proceedings of the Zoological Society of London, vol. 45 , no. 1 , p. 168-187.

BERGER, AJ., 1960. Some anatomical characters of the Cuculidae and the Musophagidae. Wilson Bulletin, vol. 72, no. 1, p. 60-140.

BOCK, WJ., 1960. Secondary articulation of the avian mandible. The Auk, vol. 97, no. 1, p. 19-55.

FÜRBRINGER, M., 1888. Untersuchumgen zur morphologic und systematik der Vögel. Amsterdan: Von Holkema. 1751 p.

GADOW, H., 1892. Classification of birds. Proceedings of the Zoological Society of London, vol. 52, no. 1, 248 p.

HOWARD, R. and MOORE, A., 1998. A complete checklist of the birds of the world. 2 ed. London: Academic Press. 630 p.

HUGHES, JM., 1996. Phylogenetic analysis of the Cuculidae (Aves, Cuculiformes) using behavioral and ecological characters. The Auk, vol. 113 , no. 1, p. 10-22.

2000. Monophyly and phylogeny of cuckoos (Aves, Cuculidae) inferred from osteological characters. Zoological Journal of the Linnean Society, vol. 130, no. 1, p. 263-307.

HUXLEY, TH., 1867. On the classification of birds. Proceedings of the Zoological Society of London, vol. 27, no. 1, p. 415-472.

1868. On the classification and distribution of the Alectoromorphae and Heteromorphae. Proceedings of the Zoological Society of London, vol. 28, no. 1, p. 294-319.
JOLLIE, M., 1957. The head skeleton of the chicken and remarks on the anatomy of this region in other birds. Journal of Morphology, vol. 100 , no. 4, p. 389-436.

KLUGE, AG., 1989. A concern for evidence and a phylogenetic hypothesis of relationships among Epicrates (Boidae, Serpentes). Systematic Zoology, vol. 37, no. 1, p. 315-328.

LIVEZEY, BC. and ZUSI, RL., 2007. Higher-order phylogeny of modern birds (Theropoda, Aves: Neornithes) based on comparative anatomy. Zoological Journal of the Linnean Society, vol. 149, no. 1, p. 1-95. (vol. II, Analysis and discussion)

MARCELIANO, MLV., 1996. Estudo osteológico e miológico do crânio de Opisthocomus hoazin (Muller, 1776) (Aves: Opisthocomidae) comparado com algumas espécies de Cracidae, Musophagidae e Cuculidae. Boletim do Museu Paraense Emílio Goeldi, vol. 12, no. 2, p. 95-246.

MORONY Jr., JJ., BOCK, WJ. and FARRAND Jr., J., 1975. Reference list of the birds of the world. New York: American Museum of Natural History. 207 p.

PAYNE, RB., 2005. The cuckoos. Oxford: University Press. 610 p.

PAYNE, RB. and SORENSON, MD., 2005. A molecular genetic of cuckoo phylogeny. In PAYNE, RB. (Ed.). The cuckoos. Oxford: University Press. p. 68-94.

PETERS, JL., 1940. Checklist of birds of the world. Cambridge: Museum of Comparative Zoology. 223 p. (vol. 11)

PINNA, MCC., 1991. Concepts and tests of homology in the cladistic paradigm. Cladistics, vol. 7, no. 1, p. 367-394.

POSSO, SR., 1999. Osteologia craniana dos Cuculiformes do Novo Mundo (Aves) com implicações sistemáticas. Botucatu: Universidade Estadual Paulista. 142 p. [Dissertação de Mestrado].

POSSO, SR. and DONATELLI, RJ., 2001. Cranial osteology and systematics implications in Crotophaginae (Aves, Cuculidae). Journal of Zoological Systematics and. Evolutionary Research, vol. 39 , no. 1 , p. 247-256.

2005. Skull and mandible formation in the cuckoo (Aves, Cuculidae): contributions to the nomenclature in avian osteology and systematics. European Journal of Morphology, vol. 4/5, no. 1, p. 163-172.

2006. Análise filogenética e implicações sistemáticas e evolutivas nos Cuculiformes (Aves) com base na osteologia, comportamento e ecologia. Revista Brasileira de Zoologia., vol. 23, no. 3 , p. $608-629$.

PYCRAFT, WP., 1903. Contributions to the osteology of birds. Proceedings of the Zoological Society of London, no. 61, p. 258-291. (parte 6, Cuculiformes)

SEIBEL, DE., 1988. A phylogenetic analysis of the Cuculiformes and Opisthocomus, based on post-cranial skeletal characters. Kansas: University of Kansas. 187 p. [Tese de Doutorado].

SHUFELDT, RW., 1901. The osteology of the cuckoos. Proceedings of the American Philosophy Society, vol. 19, no. 4, p. 4-51.

SIBLEY, GC. and AHLQUIST, JE., 1990. Phylogeny and classification of birds. New Haven and London: Yale University Press. 976 p.

VERHEYEN, R., 1956. Contribuition à l'anatomie et à la systématique des tauracos (Musophagi) et des coucous (Cuculiformes). Bulletin of the Institution Royal Scientific Nattural Belgique, vol. 32, no. 23, p. 1-28.

ZUSI, RL. and LIVEZEY, BC., 2000. Homology and phylogenetic implications of some enigmatic cranial features in Galliformes and Anseriformes birds. Annals of Carnegian Museum, vol. 69, no. 3, p. $157-193$ 